\section{Biochemical Findings in an Atypical Case of Kala Pathar (Paraphenylenediamine) Poisoning}

Paraphenylenediamine (PPD) is an organic compound with chemical formula $\mathrm{C}_{6} \mathrm{H}_{4}\left(\mathrm{NH}_{2}\right)_{2}$. It is an aromatic amine, solid and white in color, which turns black on oxidation and is a main ingredient of many locally produced hair dyes. PPD is highly toxic compound, which causes significant damage to tissues and induces hypersensitivity allergic reactions. ${ }^{1}$ It causes skeletal and cardiac muscle necrosis, causing renal tubular occlusion due to myoglobin casts. It is also directly toxic to renal tubules. ${ }^{2}$ Here, a case of acute PPD poisoning with atypical presentation is reported.

A 24-year male presented in Trauma Centre with history of kala pathar ingestion 4 days back with suicidal intent. He had complaint of generalised myalgia and headache with decreased urine output. Clinically, he was alert, well oriented and afebrile. There was no neck swelling. His blood pressure was 150/110 $\mathrm{mmHg}$; heart rate was 90 beats/min, and respiratory rate was 20 breaths/min. Systemic examination was unremarkable exceptfor muscletendernessand rigidity. Totalleukocyte count was $17.3 \times 10^{9} / \mathrm{L}$ (normal: $4-11 \times 10^{9} / \mathrm{L}$ ), with $95 \%$ neutrophils (normal: $55-70 \%)$. hemoglobin $(\mathrm{Hb})$ was $12.7 \mathrm{~g} / \mathrm{dl}$ (normal: $14-18 \mathrm{~g} / \mathrm{dl}$ ), red blood cell count was $4.43 \times 10^{12} / \mathrm{L}$ (normal: $4.52-5.90 \times 10^{12} / \mathrm{L}$ ), platelet count, $184 \times 10^{9} / \mathrm{L}$ (normal: 150 to $400 \times 10^{9} / \mathrm{L}$ ) and mean corpuscular volume (MCV) was 81.3 fL (normal: 80-95 fL). His Biochemical Profile was as follows (Tablel).

Table I: Biochemical profile of the patient.

\begin{tabular}{|l|l|l|}
\hline $\begin{array}{l}\text { Serum biochemical } \\
\text { markers }\end{array}$ & Level & $\begin{array}{l}\text { Normal reference } \\
\text { ranges }\end{array}$ \\
\hline Serum urea & $25.1 \mathrm{mmol} / \mathrm{l}$ & $1.2-3 \mathrm{mmol} / \mathrm{L}$ \\
\hline Serum potassium & $5.7 \mathrm{mmol} / \mathrm{l}$ & $3.5-5 \mathrm{mmol} / \mathrm{L}$ \\
\hline Serum CPK & $532,600 \mathrm{U} / \mathrm{L}$ & $25-200 \mathrm{U} / \mathrm{L}$ \\
\hline Serum AST & $12183 \mathrm{U} / \mathrm{L}$ & $5-30 \mathrm{U} / \mathrm{L}$ \\
\hline Serum Creatinine & $614 \mu \mathrm{mol} / \mathrm{L}$ & $53-106 \mu \mathrm{mol} / \mathrm{L}$ \\
\hline Serum Sodium & $128 \mathrm{mmol} / \mathrm{l}$ & $135-145 \mathrm{mmol} / \mathrm{L}$ \\
\hline Serum CK-MB & $5146 \mathrm{U} / \mathrm{L}$ & $5-25 \mathrm{U} / \mathrm{L}$ \\
\hline Serum LDH & $38844 \mathrm{U} / \mathrm{L}$ & $50-150 \mathrm{U} / \mathrm{L}$ \\
\hline $\begin{array}{l}\text { CPK: Creatinine phosphokinase, AST: Aspartate aminotransferase, } \mathrm{LDH}: \\
\text { Lactate dehydrogenase. }\end{array}$ \\
\hline
\end{tabular}

A diagnosis of acute PPD poisoning was made, based on history of ingestion and clinical signs and symptoms. Patient had severe rhabdomyolysis, acute kidney injury and acute liver injury. His urine output was nil on urinary catheterisation. He remained hypertensive and his condition deteriorated. Hemodialysis was started and he was given supportive care. Intravenous (IV) fluids, corticosteroids and bicarbonate were given. Renal biopsy was performed on $12^{\text {th }}$ day of admission and showed moderate acute tubular necrosis and neutrophilic and eosinophilic infiltrates in the interstitium. After multiple sessions of dialysis over the course of 18 days of hospital admission, his urine output remained nil. His overall condition improved and he requested to be discharged. At the time of discharge, his blood pressure was 140/90 and he still had no urine output. He was prescribed antihypertensives, and advised hemodialysis thrice weekly. During follow-up, his urine output and kidney functions slowly improved to normal and hemodialysis was stopped.

Over the past few decades, PPD ingestion has become an emerging trend in regions of Punjab and Sindh in Pakistan and also in India and Africa. Though the government placed ban on sale and purchase of kala pathar in several districts of south Punjab in 2017, it still remains an important but under-documented cause of morbidity and mortality in Pakistan. ${ }^{3}$ A study from Multan, Punjab showed that $82.8 \%$ of all patients ingested it with suicidal intent, with $97 \%$ of the patients being females. ${ }^{2}$

Angioedema, a common presentation of PPD poisoning is edema of the deep dermis and subcutaneous tissues. Several studies have reported cervicofacial edema to be the characteristic and early symptom of this condition, followed by acute renal failure..$^{4-6}$ However, our patient did not develop angioedema. Among the biochemical markers, highest creatine phosphokinase (CPK) level reported in one study was $281,000 \mathrm{IU} / \mathrm{L}$. Our case had CPK level of 532,600 IU/L, which is a rare finding. That, along with absence of cervico-facial edema, makes it an unusual case among other reported cases of PPD toxicity.

PPD is a easily available and cheap compound. Its use has significantly increased especially for the purpose of suicide. There is immediate need of awareness in public regarding its devastating health consequences. Atypical PPD poisoning cases need to be studied in more detail, so that physicians be aware of its atypical presentations and can make a timely diagnosis in case the patient does not reveal history of ingestion. A timely diagnosis can be life-saving as PPD poisoning has high mortality; and no antidote is available.

\section{CONFLICT OF INTEREST:}

The authors declared no conflict of interest.

\section{AUTHORS' CONTRIBUTION:}

WH: Monitoring of patients.

MAK: History taking.

MY: Literature review.

\section{REFERENCES}

1. Benslama A, Moutaouakkil S, Mjahed K, Moknia ME, Lahbil $\mathrm{D}$, Fadel $\mathrm{H}$. Intermediary syndrome in acute malathion poisoning. PresseMedicale 1998, 27(15):713-15.

2. Akbar MA, Khaliq SA, Malik NA. Kala pathar (paraphenylenediamin) intoxication: A study at Nishtar Hospital, Multan. Nishtar Med J 2010; 2:111-15.

3. Kondle R, Pathapati RM, Saginela SK. Clinical profile and 
outcomes of hair dyepoisoning in a teaching hospital in Nellore. ISRN Emerg Med 2012; 2012:5.

4. Nott HW. Systemic poisoning by hair dye. Br Med J 192; 1(3297):421-2. doi: 10.1136/bmj.1.3297.421.

5. Khan H, Khan N, Khan N, Ahmad I, Shah F, Rahman AU, et al. Clinical presentation and outcome of patients with paraphenylenediamine (kala-pathar) poisoning. Gomal J Med Sci 2015; 14(1):3-6.

6. Naqvi R, Akhtar F, Farooq U, Ashraf S, Rizvi SA. From diamonds to black stone; myth to reality: Acute kidney injury with paraphenylene diamine poisoning. Nephrology (Carlton) 2015; 20(12):887-91. doi:10.1111/nep.12534.
Waqas Hanif, Mehreen Aftab Khan and Muhammad Younas ..................................

Department of Chemical Pathology, Combined Military Hospital (CMH), Multan, Pakistan

Correspondence to: Dr. Waqas Hanif, CMH Multan E-mail: drwaqas10@yahoo.com

Received: June 27, 2019; Revised: July 18, 2020; Accepted: August 14, 2020

DOI: https://doi.org/10.29271/jcpsp.2020.11.1241 